\title{
The Role of Judges in Legal Theory AND \\ THE ROLE OF Legal THEORISTS IN JUDGING (OR 'DON'T Let THE BaStaRaChes GRIND YOU Down')
}

\author{
ALLAN C. HUTCHINSON
}

What is the future of law reviews? And does it matter? These are important questions, at least to legal academics and the students who run them. Whether the world would be any worse off if law reviews ceased to exist or, more realistically, if the number of law reviews was significantly reduced is moot at best. In this regard, the central challenge to law reviews is provided by the Internet. Its capacity to revolutionize the rarefied culture of law reviews and legal scholarship is profound and presents opportunities and threats that many have only begun to imagine or realize. Nevertheless, assuming that law reviews are likely to be around in considerable numbers for the next little while whether in electronic form or not (and I leave this issue to others more familiar with the technological media) I want to concern myself with the substance of what law reviews publish. In particular, I want to explore briefly the relationship between adjudication and legal theory as mediated and nurtured by law reviews. However, in the short space available, I will concentrate on only one, but a seriously important, dimension of this relationship - I will propose the kind of substantive content which law reviews should not be including and the kind of audience to which law reviews should not be catering. So that there is no mistaking my stance, I maintain that law reviews do a disservice to themselves and the idea of legal scholarship generally when they pander to those judges and academics who insist that the adjudicative function is at the heart of the legal enterprise and is the raison d'être of legal scholarship.

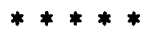

Let me begin with an example of the kind of scholarship that law reviews should, at the very best, be leery of and, at the worst, be downright dismissive of. It is a piece by the Honourable Mr. Justice Michel Bastarache of the Supreme Court of Canada, and, appropriately, it was published in this journal a couple of years ago. I hold no brief against Justice Bastarache as either judge or person. But I do take exception, as an academic, to the thrust of his particular call to arms; the fact that the judge was also a career academic before his judicial appointment is tartly pertinent. The essay's particular appeal is that it calls upon legal academics to engage in exactly the scope and substance of legal scholarship that law reviews should be at pains to avoid. In brief terms, Bastarache asks legal academics to consider refocusing their intellectual energies so that they eschew the more abstract and arid endeavours of jurisprudence and offer a more practical and grounded mode of juristic scholarship - "Academic commentary that is useful to judges is that which assembles and rationalizes judicial decisions in a given field of law, draws out the general principles that these decisions imply, criticizes judicial

Professor, Osgoode Hall Law School, York University, Toronto. This comment is based on the paper presented to the session: "The Role and Future of the Law Review" at the Annual Meeting of the Canadian Association of Law Teachers, 28 May 2000. The comment is a response in part to a presentation given by the Honourable Mr. Justice Bastarache, infra note 1 . 
decisions and suggests different approaches to particular areas of law."' This plea for a more "useful" style of legal scholarship is a little surprising in that most legal scholarship is already committed to such a project. However, insofar as Bastarache is setting new goals for legal academics and mindful of his elevated position in the legal hierarchy, it is an entreaty that cannot be ignored and must be met with a robust rejection.

Although some maintain that the last twenty years have been "a golden age for ... legal scholarship,"2 others have argued strenuously that it has been a lamentable phase in which practical relevance has been sacrificed to theoretical indulgence. For instance, Judge (and former law professor) Harry Edwards has chastised academics for their abandonment of the traditional scholarly virtues of relevance and practicality in favour of the more dubious qualities of scholasticism and aridity. ${ }^{3}$ He urges that there ought to be a return to the traditional role of legal scholarship as a practical and doctrinal critique. While it ought to be more relevant and less sophisticated, the general aim is for legal academics to act as helpmates to the courts so that they can develop areas of the law in a technically sound and substantively fair way; criticism tends to be piecemeal, specific, and constructive. In his essay, Michel Bastarache adds his own distinctive Canadian voice to this developing chorus.

Noting that there has been an increased reliance on both legal and non-legal academic work since the introduction of the Canadian Charter of Rights and Freedoms ${ }^{4}$ twenty years ago, Bastarache urges a move away from the kind of analytical legal theory that functions "in terms of abstract, logically coherent, formal conceptual systems" and "promotes stability and coherent changeability by affecting the substantive content of rights and by providing a rational basis for judicial decision-making." ${ }^{5} \mathrm{He}$ laments such a preoccupation on three grounds. First, he maintains that such a jurisprudential perspective "presupposes a metaphysically untenable idea of objective moral truth." Second, he highlights the fact that such theorizing "is impractical in that it does not sufficiently attend to what works in real life." Third, he contends that legal theory "does not accurately describe what judges actually do when they reason through cases." By way of conclusion, he also points out that adjudication is pluralistic in that it concerns

M. Bastarache, "The Role of Academics and Legal Theory in Judicial Decision-Making" (1999) 37 Alta. L. Rev. 739 at 740 . This is a publication of an oral address made to the students of the Law Faculty, University of Alberta, 20 November 1998.

2 J.H. Langbein, "Scholarly and Professional Objectives in Legal Education: American Trends and English Comparisons" in P. Birks, ed., Pressing Problems in the Law: What Are Law Schools For? vol. 2 (Oxford: Oxford University Press, 1996) at 6.

See H.T. Edwards, "The Growing Disjunction Between Legal Education and the Legal Profession" (1992) 91 Mich. L. Rev. 34, and "The Growing Disjunction Between Legal Education and the Legal Profession: A Postscript" (1993) 91 Mich. L. Rev. 2191, and "Another Postscript to The Growing Disjunction Between Legal Education and the Legal Profession" (1994) 69 Wash. L. Rev. 561. For a survey of the ensuing debate, see M.J. Saks et al., "Is There a Growing Gap among Law. Law Practice and Legal Scholarship?: A Systematic Comparison of Law Review Articles One Generation Apart" (1996) 30 Suffolk U.L. Rev. 353.

4 Part I of the Constitution Act. 1982, being Schedule B to the Canada Act 1982 (U.K.). 1982, c. II [hereinafter Charter].

s Bastarache, supra note 1 at 739.

- Ibid. at $\mathbf{7 4 0 .}$ 
itself with more than legal theory and "is guided by a search for the correct balance of all relevant factors."7 In order to achieve this more practical and pragmatic approach, Bastarache recommends the virtues of what he calls "implicit legal theory," which is "that body of doctrinal legal knowledge that is contained in the pages of treatises and law review articles and that is the result of academic conferences where the true meaning of concepts and principles that we have long taken for granted are discussed."

This form of legal theory is taken by Bastarache to incorporate a number of different and equally useful genres. He identifies three main approaches - an explanatory legal theory which "attempts to describe facts, identify causes for positive phenomenon and explain how things function"; a more critical and predictive version which "attempts to determine how a particular area of the law could be improved by means of achieving certain ideal purposes"; and a more normative kind of legal theory which "seeks to determine what judges should ultimately value when confronted with particular legal issues." Utilizing the area of family law as a forcing ground for his ideas and comments, Bastarache illustrates how such legal scholarship has been invaluable in helping judges by making sense (i.e., "the act of drawing out implicit legal policy and seeking higher levels of comprehension and articulation of legal ideas") of a complex and dynamic series of issues. ${ }^{10}$ Although he has reservations about whether academic commentary drove or simply supported doctrinal developments, he is in no doubt that it is incumbent on judges to draw upon the vital work of academic jurists. For him, there is no question that the choice between this theoretical approach and others is a no-brainer - "Should we, as judges, be cognizant only of the strict legal issue before us and the incremental evolution of the common law through precedent, or should we be open to new approaches and commentary by academics who monitor the law in a given area and reconcile it with broader social and legal issues?""

There is much to admire in Bastarache's dismissal of analytical jurisprudence with its precious emphasis on abstraction and its overweening respect for coherence. However, there is little reason to believe that Bastarache's alternative has more to recommend it. Indeed, his proffered alternative is more a variant on analytical jurisprudence than an alternative to it. Apart from drawing on the dubious virtue of "principled consistency," Bastarache does much to tout the validity of traditional legal scholarship, suitably lifted a theoretical notch or two. There is little in Bastarache's essay that reassures the reader that the move that he counsels is anything more than a shift from black-letter law to black-letter theory. Moreover, the underlying thrust of Bastarache's whole essay is to confirm that the benchmark of valid legal scholarship is its capacity to contribute to the better performance of the judicial task. As he concludes:

In the end, judges decide. Decisions are not legal articles... [T] here is danger in quoting "unhelpful" academic materials and thereby suggesting they are more valid because they are adjuncts to the judicial

Ibid.

Ibid.

Ibid. at 740-41.

Jbid. at 742 .

lbid. at 741-42. 
process. But then again, we must not ignore academic contributions by concluding too rapidly that they are only "opinions."12

After canvassing the present state of legal scholarship, I will connect Bastarache's comments with the continuing debate in jurisprudential circles and offer a different account of what might amount to "useful" legal theory.

There is little different in the overall law review content from the situation twenty years ago - there is simply more of it. Harry Arthurs survey of Canadian academic research remains almost as valid today as it was twenty years ago. In Law and Learning, he mapped the intellectual landscape on planet Canadian Law. He discovered a uniform terrain which, apart from the occasional exotic hot spot, was rather flat and uninspiring; there was little that was likely to trouble or challenge the traditional explorer. Indeed, the modern Canadian legal scene offers ample demonstration of the old adage plus ça change, plus c'est la même chose. While there has been a significant increase in the amount of interdisciplinary work done by legal scholars, the fact is that a great deal of that work has been harnessed to the traditional academic task of performing "taxonomic" scholarship (i.e., the classification and organization of legal rules). The performance of this traditional task has become much more sophisticated, but it remains devoted to the same set of goals and ambitions. ${ }^{13}$ The ability of mainstream scholarship to absorb and neutralize new insights and fresh perspectives on the study of law is truly staggering. Indeed, its intellectual agility in doing this is to be admired, although it is a great pity that such a prodigious talent cannot be put to more rewarding and less toadying effect. In short, there has been something of a shift from black-letter lawyering, but it has not gone much further than black-letter theorizing. Much academic work continues to operate within the cramping and pervasive spirit of a black-letter mentality that encourages scholars and jurists to maintain legal study as an inward-looking and self-contained discipline. There is still a marked tendency to treat law as somehow a world of its own that is separate from the society within which it operates and purports to serve. In a manner of speaking, the ghosts of Blackstone and Coke not only prowl the corridors of academe, but are welcome souls in its offices and classrooms.

When it comes to thinking about the adjudicative role, most Canadian academics still exist in a semi-conscious state in which the illusions of noble dreams and ignoble nightmares still hold sway. ${ }^{14}$ The overriding problem though is that it is not entirely clear which is the dream and which is the nightmare - the choice between a vision in which judges admit to making law and one in which they claim to be simply applying it will depend on whether it is really possible to apply law without also making it, and whether the law to be applied is substantively superior to what judges might have decided

1: $\quad$ Jbid. at 747.

1: See Canada, Law and Learning: Report to the Social Sciences and Humanities Research Council of Canada (Ottawa: The Council, 1983) (Chairman: H.W. Arthurs).

is See H.L.A. Hart, "American Jurisprudence Through English Eyes: The Nightmare and The Noble Dream" (1977) 11 Geo. L. Rev. 969 at 989. 
for themselves. Indeed, it is my view that the courts cannot do one without also doing the other - applying the law involves choice as much as that choice involves reference to existing law; it is a constant and organic interaction between choice and constraint, between amendment and application, and between direction and discretion. ${ }^{15}$ In a manner of speaking, judges will never get a good night's sleep (nor should they) as they are destined to struggle with the heavy responsibilities of doing justice. The best that they can hope for is that they will do enough good in their waking hours that they can get enough sleep to refresh them for the next day's challenges. Judges who sleep without dreams and/or nightmares are either so smugly confident as to question their ability to do justice in a world in which what justice demands is always changing, or they are so anxiously overwrought as to undermine their capacity to make difficult decisions in difficult circumstances. Doing justice through law, if that is not oxymoronic, requires judges to concern themselves more with the bracing light of day than the confusing shadows of night. In this, Bastarache is correct: good judging is about much more than getting the theory right.

Unfortunately, the whole premise of Bastarache's article persists in reinforcing the tragically mistaken view that courts are the centre of the legal universe in that what they do is law and what everybody else does is comment on it and suggest better ways to catalogue and organize it. This is nicely ironic because, while claiming to take a quite formalistic stance on law, he actually subscribes to a very realist sense of legal practice. Throughout his essay, Bastarache emphasizes that adjudication is not an exercise in abstract theorizing, but rather it is about dealing with particular problems in particular circumstances. Nevertheless, Bastarache's court-centred view of the legal universe is eagerly embraced by jurists themselves. Indeed, many legal academics can think of no more a compliment than to be cited by the Supreme Court of Canada. And the more such compliments the merrier. These citations are considered to be the very height of professional achievement and are highly coveted; they are a signal honour, a notch on the belt of academic merit, and a feather in one's scholarly cap all rolled into one. I have to concede that I have had that dubious distinction on a couple of occasions. But I have tried hard to resist the urge for celebration. I like to think that I attain my professional validation and esteem in other ways. And that is the issue - what is it that academics should be doing? How is the academic responsibility different to the judicial one? And how can law reviews help in facilitating that role?

At bottom, the answers come down to insecurity and academics' lack of self-worth. If academics had a better sense of themselves, they might care less what the judges thought about them and whether their work received judicial approval. Of course, it is alright to support a particular decision of the Supreme Court or to offer suggestions on what it should be doing. But it is the idea that such a servile task goes to the heart of what it means to be a serious and successful academic that is the problem. When law professors define themselves as lackeys for their judicial superiors, they deserve no better (or worse) treatment than such ne'er-do-wells. Academics betray the academic cause when they align themselves so uncritically with the interests of the establishment. Instead of trying to make 
a silk purse out of a sow' ear, what academics should be doing is calling a spade a spade or a pig's ear a pig's ear. Being helpmates to the judiciary is not an easy job, but it is surely not the role of academics to work only as "constructive clerks" for the judiciary. And, when you consider that many clerks become professors, there is much to be concerned about. Imagine political scientists who construed their whole endeavour to be cheerleaders for the government on the basis that one day they might become one of them. This chilling vision is at the critical heart of Duncan Kennedy's thesis on training for hierarchy with a vengeance. ${ }^{16}$

So what are scholars doing exactly? What are judges doing exactly? On first reading, Bastarache seems to be very much part of the mainstream with his emphasis on the need for order and coherence, his praise for established academics and their modus operandi, and his presentation of the adjudicative task as a largely philosophical rather than political undertaking. However, on a closer rereading, there are distinct and subtle hints that Bastarache himself is not all convinced by the designated roles of academics and judges that he forefronts. The question he raises about "whether judges simply use academic writings and legal theories to support views they already hold or whether judges draw on legal theory and academic writings when they make their initial decisions and form their preliminary opinions about the nature of a case," 17 seems to be answered in a way that suggests that rationalization, not reasoning, is the main name of the academic game. After all, Bastarache does conclude by stating that "judges decide. Decisions are not legal articles." 18

A number of years ago, I got very exercised about the Supreme Court's efforts to develop a doctrine of "government action" under s. 32 of the Charter. ${ }^{19}$ In the McKinney case, the court did a dog's breakfast of a job in attempting to explain why hospitals and universities were not governmental agencies (and, therefore, not subject to Charter scrutiny) but community colleges were. ${ }^{20} \mathrm{I}$ tried to show that the Court was entirely lost in a maze of its own making; there was no escape from the public-private distinction that it hoped would resolve the law-politics distinction that plagued the courts in their interpretation of the Charter. It was not so much that cooking up a dog's breakfast (as opposed to some more pleasing repast) was the problem, but that a dog's breakfast was the only possible dish that could be made from the available Charter ingredients. Still, for many, a dog's breakfast was better than no breakfast at all, and the Court and its legions of academic sous-chefs sought to package the resulting recipe as more nouvelle cuisine than traditional fare. However, some traditional academics, even those who were committed members of the Charter Lovers party, were dismayed at the Court's performance and took seriously the criticisms of incoherence and irrationality that were levelled at the s. 32 doctrine. But, open as they were and complimentary of the critical

16. See D. Kennedy, Legal Education and the Reproduction of Hierarchy: A Polemic Against the System (Cambridge: Afar, 1983).

17 Bastarache, supra note 1 at 741.

Ix Ibid. at 747.

1") Although I originally published the piece in the newspaper, $I$ included it in slightly more measured terms in A.C. Hutchinson, Waiting for Coraf: A Critique of Lav and Rights (Toronto: University of Toronto Press, 1995) at 144-47 [hereinafter "Coraf']. 
work offered, they remained frustrated at my own and other critics' unwillingness to be more constructive and less negative. A senior colleague (who is now a successful and liberal-minded judge) simply wanted to know what was to be done - "But what should the Court do? What can be done that is coherent and conscionable? You have only done half the job: you need to tell the court what they should have done or else your criticisms will not be taken seriously - you need to get in the game, not stand on the sidelines scoffing at the poor play." I suppose that it all depends on what you think that the game is, who are its main players, and what it means to be victorious. It is to sketching a different sense of "useful" jurisprudence that I now turn.

While most lawyers and legal theorists are still prepared, through a combination of intellectual naivety, institutional allegiance and political advantage, to buy into the possible realization of jurisprudence's philosophical project or, at least, to tolerate it as a noble undertaking, a number of critics refuse to accept such a pretence. They realize that more is to be achieved by practical and unpretentious interventions than by grand and arcane gestures. Indeed, rather than perpetuate popular enthraldom to the vague cause of philosophical enlightenment, the need for there to be critical disenchantment in the name of democratic empowerment is fully recognized. When viewed in these terms, the pressing question of how people should live or think about law becomes not a methodological puzzle of abstract dimensions, but a substantive challenge of historical proportions. There is neither universal Truth nor suprahistorical Knowledge, but only the human effort to do the best that we can with full range of human resources at our disposal. And this first demands a switch in jurisprudential attention from the pursuit of metaphysical truth (even the watered down Bastarachian version) to the practice of political usefulness - a juristic account or proposal is mistaken not because it is philosophically wrong, but because it is not practically useful. For Bastarache, "useful" is exhausted in some philosophical and apolitical sense.

Dumping grand theory does not entail a resigned relativism in which each and every idea or claim is as good as any other. Pragmatists take the view that all cultures are not equal, but that all do have something to contribute to debate. Justification is a practice, and what works will depend on the context in which justification is offered and heard. It is not about striving to reach a promised land of truth that will make further justification unnecessary. Instead, jurisprudence must become more useful such that success is not vouchsafed by reliance upon a particular epistemic method, but by the usefulness of the results arrived at and their effect upon meeting certain objectives that are taken to be morally or politically significant: "pragmatists see the charge of relativism as simply the charge that we see luck where our critics insist on seeing destiny."21 Pragmatists, like Rorty, prefer hope over knowledge and insist that moral choice is always a matter of compromise between competing goods rather than a choice between the absolutely right and the absolutely wrong. ${ }^{22}$ Instead of reflecting upon universality to justify particular principles, there should be talk about the concrete and relative advantages of choosing one 
over another in particular circumstances. There is only justification; it neither leads to nor is it underwritten by truth, but it is to be judged by its contribution to democratic agreement and greater emancipation. In an important sense, therefore, the alternative to knowingness is not ignorance, but awe and wonder. And the alternative to theory is not practicalism, but romance and politics. By seeing itself as a tool which can be used to spark the imagination and create hope in people for the improvement of society, jurisprudence will become more useful and relevant, not less.

In advocating a useful jurisprudence, I ought not to be taken as championing some fixed or foundational idea of usefulness that is intended to inform and guide practice. On the contrary, I want to ensure that this definitional effort is a integral part of the very argumentative culture that develops and allows transformations of what is and is not useful. This means that "[i]nstead of seeing progress as a matter of getting closer to something specifiable in advance, [pragmatists] see it as a matter of solving more problems ... [and it is] measured by the extent to which we have made ourselves better than we were in the past rather than by our increased proximity to a goal."23 Consequently, the emphasis on usefulness is not another disguised strategy of Casaubonic theorizing in which usefulness replaces integrity or purity as the underlying standard of jurisprudential worth. In moving from truth to usefulness, a pragmatic jurisprudence does not set out to know things as they really are or to isolate a universal criterion of usefulness. Because usefulness is a continually contested and contextualized yardstick, it begs to be judged by its contribution to the ambitious project of challenging the present arrangements in order to improve the future. To do this, jurisprudence requires a different vocabulary more suited to its practical demands. There must be less formal talk of integrity, consistency, and harmony and more substantive talk of justice, well-being, and empowerment. Although pragmatism cannot answer the compelling question of what to do next? in any fixed or certain way, it can encourage the jurisprudential effort to ensure that valuable energies are not wasted on pseudo debates about truth and objectivity. In doing so, it will become possible to open a space in which people can engage directly about what is more and less useful in specific contexts at specific times.

One way to advance that useful agenda is to treat the courts and common law as venues for the resolution of concrete disputes rather than as the site for the philosophical elaboration of doctrinal integrity or purity. This will demand a shift in jurisprudential emphasis from the law-making focus of judges to their problem-solving capacity. The potential strength of the common law is its practicality and situatedness: the courts must concentrate more on practical solutions to practical problems than on philosophical responses to philosophical problems. In proposing this juristic realignment, I do not want to be taken as suggesting that the common law has been or necessarily will be the perfect complement to the kind of useful approach to jurisprudence that I have been advocating. However, I do maintain that, when viewed from such a pragmatic perspective, the common law has all the possibilities to become an institutional site for the kind of experimental, contextualized, and practical interventions that I support. While the history of the common law ought not to impress the critics' sensibilities, it does not mean that 
resort to the courts is a hopeless or counterproductive diversion. Because the present is the only place to begin in making a better future, it is appropriate to utilize existing institutional arrangements at the same time that one works to effect their transformation in line with a more progressive and emancipatory ideal. ${ }^{24}$ To allow the ideal future to be the enemy of the flawed present is a recipe for resignation and complicity, not action and change. Ideological purity is no more attractive or useful than its philosophical relative.

Within such a revisioning of the common law, jurists and legal scholars can play a number of roles. Foremost among them, any study of law or ethics must not, as black letterism proposes, be done without recognizing the political context and conditions of that undertaking: the resilient black-letter practice of decontextualization must be strenuously combatted. Instead, there has to be a greater recognition that law and politics are intimately and inseparably related; it is futile and well-nigh fraudulent to study one without the other. However, the study of politics and its relationship to law is not enough in itself. That study must be done in such a way that avoids the pitfalls and problems of black letterism. There is little point in examining law's political context and determinants if it is done within the capacious reach, but narrowing influence, of a formalistic mindset. To demand anything less is to allow the lingering spirit of black letterism to intoxicate people into believing that clear directions and speedy routes can be mapped onto the messy and changing terrain of ethical and political inquiry, especially in exploring the relation of law and politics. However, as a complement (and a compliment) to the work of such legal scholars, jurists can also play an explicitly and suitably theoretical role. They can bring fresh insights and appreciations to jurisprudence. In particular, jurists can develop alternative modes of discourse, so that philosophy will become more a discourse of dissent than a monologue of reverence. Rather than draft grand schema for political or legal action under the authority of some alleged universal truth, philosophers can seek out new possibilities and alternative openings. By being activist in imagination and commitment, pragmatists will come to recognize that their philosophical task is to be as much inspired poets as robust political operatives. Or, to put it another way, jurists will recognize that the best way to do legal philosophy is to do it pragmatically, usefully, and poetically. The persistent belief that "law is the calling of thinkers," whether in the form of metaphysicians or economists, and "not the place for the artist or the poet" is to be discarded once and for all. ${ }^{25}$ The difference between art and science or between literature and philosophy is one of emphasis and practice, not essence and theory. In becoming artists and poets, jurists and legal scholars can become better thinkers.

For a more elaborate defence of this position and some suggestions for its implementation, see Hutchinson, "Game." supra note 15 at 288-319 and Hutchinson, "Coraf," supra note 19 at 172-83. It might be claimed that this essay itself is long on formal exhortations but short on substantive recommendations. I am sensitive to this charge and am presently writing a book along such lines, entitled Work-In-Progress: Common Law, Tradition and Transformation. 
But all of this is not the same as being useful in the sense of becoming helpmates to beleaguered judges. If law professors owe an allegiance, it is to the critical spirit of the institutions into which they inhabit and breathe life. This is the university and world of learning, not the relatively limited ones of law and courts. As academics, legal scholars must be devoted to the pursuit of truth and knowledge for its own sake. If they give up on that, they betray themselves as scholars as well as those who have fought to establish the protected conditions in which professors are privileged to work. Of course, what amounts to truth and knowledge is itself part of the debate that should energize universities and law schools. And, presently, it is one of the most heated on the intellectual agenda. However, you would not guess that if you spent your time only reading law reviews. Unfortunately, too many legal academics play the affected role of the naif. Occasionally, they at least have the advantage of doing so with integrity, albeit a little too gullibly. But most of the time they are simply faking it. And, as Sam Goldwyn might have said, once you can fake faking it, you've got it made (as anyone who saw Meg Ryan's performance in When Harry Met Sally will surely concede). I am not sure that $I$ would go as far as concluding that academics are acting out of bad faith. It is more a question of them letting what they perceive to be in their best interests get in the way of their intellect; it is the curse of the rose-tinted spectacles. In a time-honoured ritual, professors relate to judges like they have (or would have) their students relate to them as authoritative sources of wisdom and patronage who will repay obedience with recognition and usefulness with promotion.

The sooner legal academics (and by implication law reviews) grasp that judges and themselves are in different jobs, the better. Much as the impression to the contrary suggests, law reviews are not the home of farm teams to the Big League's major judgments. Law professors and judges are in different professions and different games. A legal scholar who wants to be a judge is no longer a scholar; they might well be elevated law clerks, and good ones at that, but they are not scholars. To be a scholar is to call life's vicissitudes as you see them, not to call them because of what you would like to see. This is not to say that scholarship that praises the court or particular decisions is bad per se; there is room for congratulation and conservatism. But it is vital that if such scholars want to remain true to their intellectual heritage, they must do so out of an abundant disregard for favour. They must at least be open to the idea that they will take the courts to task and criticize their very existence as much as the decisions that they render. In other words, academics must always be willing to call it as they see it. Without such a possibility, the legal scholar is little more than a hack who lives not for truth, but for thanks. This is the fate of the ingrate, not the intellectual.

And how do judges repay the efforts of academics and scholars? They treat them in the same way that good masters treated willing servants; they patronize them and, when it suits their immediate purpose, they put their ideas to use as packing and padding in the judicial output. Of course, when it does not serve their purpose, they either ignore them altogether or point out the error of their ways. Although academics like to think of themselves as necessary mentors to the judicial profession, they are really little more than dispensable and occasional odd-job workers; they fix a leak here or mend a fitting there, but they are not the indispensable resources that they pretend or want to be. As Bastarache condescendingly puts it, "the work of academics serves to provide a contextual social 
background for legal disputes, helps to make judges aware of the underlying reasons for the decisions that they make and offers useful suggestions for reform. No principled approach to decision-making can ignore the contribution of academics." 26

Flipping through the television channels, the Food Channel often seems to be one of the more engaging offerings. The programs are full of pizzas and pizzazz - judges are like the Emerils and Two Fat Ladies of the cooking world; they wear fancy outfits and dazzle with their artful confections. Revealingly, there are no cooking academics present; the chefs do that for themselves. The role of the food critic is much more detached and critical; it is the chefs, by and large, who must curry favour with the critics than vice versa. In law, the whole thing seems upside down - critics seems to crave the approval of those that they should be criticizing. What is required is more kick-ass, less kiss-ass. Law reviews are too much like recipe books for the privileged; they are too often satisfied to fill their pages with lessons on how to make the perfect souffle or how to confect the lightest hors d'oeuvre. In short, there is too much Julia Childs and not enough Urban Peasant.

If legal scholarship proves useful to judges, so be it - that is neither good nor bad in itself. The fact is that legal scholars should look elsewhere for their validation and prestige. For some, citation and incorporation by the Supreme Court will be the icing on the cake, but that is all it should be: the cake is what counts and that is being baked for a very different clientele. In its broadest sense, scholars ought to be feeding the hunger of society for justice. This is done not by pandering to the appetites and palates of the established and already well-fed. It is an opportunity and responsibility to provide substantive fare to those that are wasting away on a steady diet of coherent principles and rational abstraction for lack of more hearty fare. Judges and legal academics are too easily to be found in upscale restaurants than putting in their time at local soup kitchens. Or, more radically, judges and legal academics ought to be striving to do away with need for soup kitchens. It simply will not do, as many legal scholars (aided and abetted by ingratiating law reviews) seem to think in proffering their abstract accounts and logical niceties and as many judges do in preferring logical consistency over substantive justice, to utter the jurisprudential equivalents of Marie Antoinette's "let them eat cakes" - Let them have coherence. 